Case Report

\title{
PARTIALY FUSED SPLENIC LOBULE- A CASE REPORT
}

\author{
Rani Nallathamby', Ramakrishna Avadhani', Shivarama Bhat ${ }^{3}$, \\ Meera Jacob ${ }^{4} \&$ Meril Ann Soman ${ }^{5}$ \\ ${ }^{1,5}$ P.G. Student, ${ }^{2} \mathrm{HOD},{ }^{3}$ Professor, ${ }^{4}$ Assistant Professor, Department of Anatomy, \\ Yenepoya M edical College, M angalore - 575 018, Karnataka, India \\ Correspondence : \\ Rani Nallathamby \\ P. G. Student, Department of Anatomy, Yenepoya M edical College, Mangalore - 575 018, Karnataka, India. \\ Mobile : +91 8861120119 E-mail : raniboban@yahoo.com
}

\begin{abstract}
:
Spleen is the largest lymphatic organ in humans. It is situated in the left hypochondrium and partly in the epigastrium, between the fundus of the stomach and the diaphragm. It consists of large encapsulated mass of lymphoid and vascular tissues (1).We encountered a case of partially fused splenic lobule in the anterior end with attachment to the main splenic mass through a stalk of splenic tissue. As such, the variation of this kind is rare and had various important clinical implications in the field of surgery, radio diagnosis and gastroenterology.
\end{abstract}

Keywords: splenic lobule, congenital variation, splenectomy.

\section{Introduction :}

The spleen develops from the mesoderm and during its development, different lobules are formed, which fuses with each other later on which is indicated in the form of the lobulations in adult spleen that can be seen on the superior as well as on the inferior borders(2). The number of notches varies from zero to six, but commonly, only one or two notches were seen. During the development of the spleen, small masses of the splenic tissue may become detached from the main mass and may develop into accessory spleens (3). Awareness on the possible presence of the accessory spleen is important as their exclusion during splenectomy, may result in the persistence of the symptoms which indicated it. In this case report, we are presenting a partially fused splenic lobule which may present interpretation errors in diagnostic imaging. The knowledge of this variation is important anatomically, radiologically and surgically.

\begin{tabular}{|c|}
\hline Access this article online \\
\hline Quick Response Code \\
\hline
\end{tabular}

\section{Case Report:}

During routine dissection of medical undergraduates in Yenepoya Medical College, Mangalore, Karnataka; a spleen with an unusual presentation of a partially fused lobule is noted in a male cadaver of about 60 years of age. The superior aspect of the anterior end presents a lobule which is clearly separated from the main mass in its diaphragmatic surface, superior and inferior borders by a deep fissure of $16.8 \mathrm{~mm}$ depth but connected inferiorly in the visceral surface through a stalk of splenic tissue. (FIGURE.1) A leash of splenic vessels from hilum is noted to enter into this lobule through its postero-inferior aspect. The lobule is $22.1 \mathrm{~mm}$ in length, $24.8 \mathrm{~mm}$ in breadth and $11.3 \mathrm{~mm}$ in thickness. The spleen as a whole is $101.5 \mathrm{~mm}$ in length, $62.6 \mathrm{~mm}$ in breadth and $20.7 \mathrm{~mm}$ width. Its superior border presents 2 notches extending into the diaphragmatic surface. No other visible anomalies were found in other viscera of the cadaver. (FIGURE.2)

\section{Discussion:}

There is a wide range of congenital anomalies of the spleen. Some are common, such as splenic lobulations and accessory spleen. Other less common conditions, such as wandering spleen and polysplenia, have particular clinical significance. In fetal life, although spleen occurs in a lobulated form, lobules disappear prior to the child birth. In adult spleen, notches are considered as remnants of the grooves from where the fetal lobules have undergone separation (7).In the present case, a lobule in the anterior end had failed to completely fuse with the main mass. 


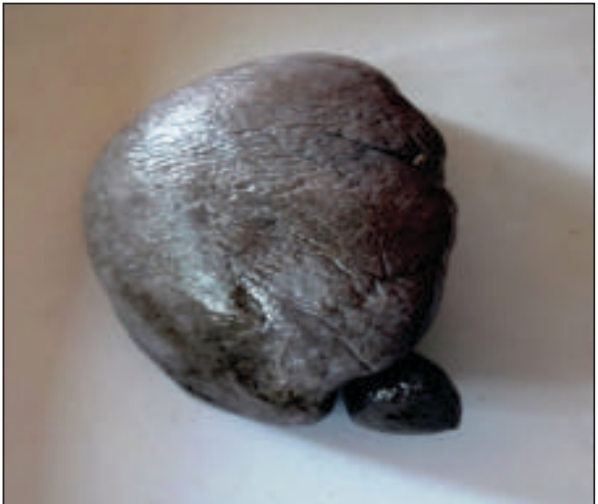

Figure.1: Spleen with the lobule at anterior end

Presence of splenic notches in the same spleen, extending more towards diaphragmatic surface as fissures also points out to defective development of the viscera. Hakk Maummer Karakas et al 2005[11] studied splenic abnormalities on CT scan and MRI. They found the congenital variations of spleen like asplenia and polysplenia syndrome. Both anomalies were associated with multiple system and organ anomalies including the liver and heart (8). ). Some research workers $[4,5,6]$ reported that the incidence of the accessory spleen to vary from 10 to $35 \%$ and they were found at the hilum of the spleen, in the gastro splenic ligament, in the greater omentum, along the pancreas, along the splenic vessels, and in the scrotum also. These congenital variations are important in surgical as well as radiological point of view. Accessory spleen and splenic lobulations can be misinterpreted as neoplasm by endoscopic ultrasound. Although homogenous, they can be hyper echoic or hypo

\section{References}

1. Standring S: Gray's Anatomy: The Anatomical Basis of the Clinical Practice, 39th edition. Edinburg: Elsevier Churchill Livingstone, 2006; 1239-44

2. Sant S. Embryology for medical students. New Delhi: Jaypee brothers' medical publishers (p) Itd., 2002; 203-04

3. Hamilton WJ, Boyd JD, M ossman HW. Human embryology - prenatal development of form and function. 4th ed. London: The Macmillan pressltd., 1978; 363-64.

4. Hollinshead WH. Anatomy for Surgeons. 3rd ed. vol-2. New York: Harper and Row, 1982; 436-45

5. Curtis GM , M ovitz D. The surgical significance of the accessory spleen. Ann Surg. 1946 February; 123(2): 276-98.

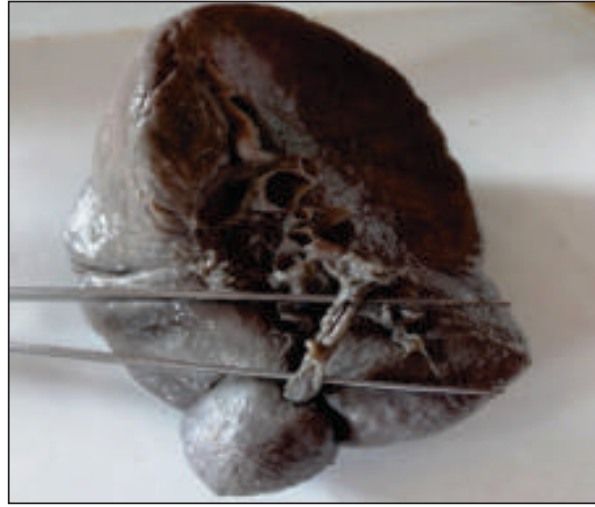

Figure $\mathbf{2}$ : Lobule with splenic vessels

echoic (9). The present variation may be misinterpreted as a traumatic injury by the radiologist and it may create confusion in clinical palpation of the enlarged spleen in splenomegaly as it may be misdiagnosed as a growth from the anterior end. Also, it may pose a problem during planning of surgeries and also in laparoscopic interventions. In this modern era of imaging and minimallyinvasive approaches, it is imperative on the side of both the radiologists and operating surgeons to have a thorough knowledge of the anatomy and the commonly-occurring variations in this organ.

\section{Conclusion:}

This case report presents a rare congenital variation of spleen, the awareness of which would be helpful for imaging specialists and surgeons, to avoid possible errors in interpretations and subsequent misdiagnosis, and also in planning appropriate surgical approaches.

6. Emmet JM, Dreyfuss ML. Accessory spleen in the scrotum. Ann Surg.1943 M ay; 117: 754-59.

7. Keith. L. Moore, T V N. Persaud. The developing human. Clinically Oriented Embryology. Elsevier, 8th Ed .223-224

8. Hakki Muammer Karakas, Nermin Tunçbilek, Ozerk Omur Okten; Splenic abnormalities: an overview on sectional images. Diagn Intervent Radiol 2005; Turkish Society of Radiology11, 2005; pp152158

9. Barawi M, Bekal P, Gress F. Division of Gastroenterology and Hepatology, Winthrop-University Hospital, State University of New York at Stony Brook, Mineola, New York 11501, USA. 2000 Dec; 52(6):769-72. 